\title{
Syntheses of Ruthenium(II) Quinonediimine Complexes of Cyclam and Characterization of Their DNA-Binding Activities and Cytotoxicity
}

\author{
Hing-Leung Chan, ${ }^{\S}$ Heng-Qian Liu, ${ }^{\dagger}$ Biing-Chiau Tzeng, ${ }^{\dagger}$ Yuan-Shyane You, ${ }^{\ddagger}$ Shie-Ming Peng, ${ }^{\ddagger}$ \\ Mengsu Yang, ${ }^{\star, \S}$ and Chi-Ming Che ${ }^{\star, \dagger}$ \\ Department of Chemistry and Open Laboratory of Chemical Biology of The Institute of Molecular \\ Technology for Drug Discovery and Synthesis, The University of Hong Kong, Pokfulam Road, \\ Hong Kong, Department of Chemistry, National Taiwan University, Taipei, Taiwan, and \\ Department of Biology and Chemistry, City University of Hong Kong, \\ 83 Tat Chee Avenue, Hong Kong
}

Received December 14, 2001

\begin{abstract}
The synthesis and characterization of ruthenium(II) complexes, $[\mathrm{Ru}(\mathrm{cyclam})(\mathrm{bqdi})] \cdot \mathrm{ZnCl}_{4}\left(1 \cdot \mathrm{ZnCl}_{4} ; \mathrm{cyclam}^{2}=1,4,8,-\right.$ 11-tetraazacyclotetradecane, bqdi $=0$-benzoquinonediimine), $[\mathrm{Ru}(\mathrm{cyclam})(\mathrm{nqdi})] \cdot\left(\mathrm{ClO}_{4}\right)_{2}\left(\mathbf{2} \cdot\left(\mathrm{ClO}_{4}\right)_{2}\right.$; nqdi $=2,3-$ naphthoquinonediimine), and $[\mathrm{Ru}(\mathrm{cyclam})(\mathrm{phi})] \cdot\left(\mathrm{ClO}_{4}\right)_{2}\left(3 \cdot\left(\mathrm{ClO}_{4}\right)_{2} ; \mathrm{phi}=9,10\right.$-phenanthroquinonediimine $)$, are described. The DNA binding properties and biological activity of the Ru(II) complexes were studied by various biophysical and cytological techniques. As expected, only 3 showed significant binding with DNA. The thermodynamic profile of the binding of 3 and DNA was constructed by analyzing the experimental data of absorption titration and UV melting studies with the McGhee equation, van't Hoff's equation, and the Gibbs-Helmholtz equation. Compound 3 binds double-stranded DNA with a binding constant of $5.0 \times 10^{4} \mathrm{M}^{-1}$ at $20^{\circ} \mathrm{C}$, and the binding mode of the complex to DNA was proved to be intercalative. Cytotoxicity and induced type of cell death of 1-3 were also investigated. Basically, metal complexes with ligands of molecular shape closely related to the structure of DNA are more likely to bind DNA and possess higher toxicity.
\end{abstract}

\section{Introduction}

There have been intensive efforts in investigating those factors that determine affinity and selectivity in binding of small molecules to DNA. ${ }^{1}$ Any information about those factors that determine the binding of small molecules to DNA would be invaluable in the rational design of sequencespecific DNA binding molecules for application in chemotherapy and in the development of tools for biotechnology. ${ }^{1 f}$

Intercalators usually have planar aromatic ring systems that occupy the space between two adjacent DNA base pairs.

* Authors to whom correspondence should be addressed. E-mail: bhmyang@cityu.edu.hk (M.Y.); cmche@hkucc.hku.hk (C.-M.C.).

$\dagger$ The University of Hong Kong.

$\doteqdot$ National Taiwan University.

$\S$ City University of Hong Kong.

(1) (a) Barton, J. K. Science 1986, 232, 727-734. (b) Dervan, P. B. Science 1986, 232, 464-471. (c) Wade, W. S.; Dervan, P. B. J. Am. Chem. Soc. 1987, 109, 1574-1575. (d) Kissinger, K.; Krowicki, K.; Dabrowiak, J. C.; Lown, J. W. Biochemistry 1987, 26, 5590-5595. (e) Quigley, G. J.; Ughetto, G.; van der Marel, G.; van Boom, J. H.; Wang, A. H.-J.; Rich, A. Science 1986, 232, 1255-1258. (f) Pyle, A. M.; Rehmann, J. P.; Meshoyrer, R.; Kumar, C. V.; Turro, N. J.; Barton, J. K. J. Am. Chem. Soc. 1989, 111, 3051-3058.

10.1021/ic0112802 CCC: $\$ 22.00$ (C) 2002 American Chemical Society Published on Web 05/17/2002
Examples of intercalators include ethidium bromide (EB), acridine orange, and doxorubicin. The ligand-DNA adduct is stabilized by hydrogen bonds and $\pi-\pi$ stacking. To design and synthesize novel DNA structural probes and anticancer drugs, it is important to know how existing DNA binding small molecules interact with DNA. As a result, the elucidation of noncovalent interactions with DNA by small natural products and their synthetic derivatives has drawn a lot of attention from many researchers. ${ }^{2}$

Many octahedral complexes of $\mathrm{Ru}(\mathrm{II}), \mathrm{Re}(\mathrm{I}), \mathrm{Rh}(\mathrm{III})$, and $\mathrm{Co}(\mathrm{III})$ have been proved to bind with DNA intercalatively. ${ }^{3}$

(2) (a) Friedman, A. E.; Chambron, J.-C.; Sauvage, J.-P.; Turro, N. J.; Barton, J. K. J. Am. Chem. Soc. 1990, 112, 4960-4962. (b) Barton, J. K.; Kumar, C. V.; Turro, N. J. J. Am. Chem. Soc. 1986, 108, 63916393. (c) Hiort, C.; Lincoln, P.; Norden, B. J. Am. Chem. Soc. 1993, 115, 3448-3454. (d) Naing, K.; Takahashi, M.; Taniguchi, M.; Yamagishi, A. J. Chem. Soc., Chem. Commun. 1993, 402-403. (e) Barton, J. K.; Lolis, E. J. Am. Chem. Soc. 1985, 107, 708-709. (f) Jenkins, Y.; Barton, J. K. J. Am. Chem. Soc. 1992, 114, 8736-8738.

(3) (a) Mesmaeker, A. K.-D.; Orellana, G.; Barton, J. K.; Turro, N. J. Photochem. Photobiol. 1990, 52, 461-472. (b) Kielkopf, C. L.; Erkkila, K. E.; Hudson, B. P.; Barton, J. K.; Rees, D. C. Nat. Struct. Biol. 2000, 7, 117-121. (c) Zhang, Q.; Liu, J.; Xue, G.; Li, H.; Liu, J.; Zhou, H.; Qu, L.; Ji, L. J. Inorg. Biochem. 2001, 85, 291-296.

Inorganic Chemistry, Vol. 41, No. 12, 20023161 
The binding of cationic Ru(II) complexes to nucleic acids has been the subject of considerable investigation. ${ }^{2,4} \mathrm{Ru}(\mathrm{II})$ complexes have been used in the studies of ligand-DNA interaction because of the kinetically inert character of the low-spin $\mathrm{d}^{6}$ species and the intense metal to ligand charge transfer (MLCT) band in the visible spectrum. ${ }^{4 a}$ Cyclam and other tetraazacyclic compounds have long been the most useful and versatile prototype of polyamine compounds for fundamental and applied chemistry, ${ }^{5}$ and the interest in their biological properties has also been growing. ${ }^{6}$ Although $\mathrm{Ru}$ (II) complexes with $o$-quinodiimine ligands were synthesized by other researchers, their DNA binding properties were not studied. ${ }^{7} \mathrm{Ru}$ (II) diimine complexes of cyclam have never been reported, and their intense MLCT bands in the visible region would be useful for DNA binding study. ${ }^{8}$ The amines of the ancillary, nonintercalating ligand cyclam may provide hydrogen bonding with the functional groups positioned in the edges of the DNA bases. ${ }^{3 b}$ In this binding study of $\mathrm{Ru}(\mathrm{II})$ complexes with DNA, we designed a series of novel $\mathrm{Ru}$ (II) quinonediimine complexes of cyclam. The quinonediimine ligands used consisted of different numbers of conjugated benzene rings, and they protruded from the central $\mathrm{Ru}(\mathrm{II})$ atom to different extents. On the basis of the molecular structures of the $\mathrm{Ru}(\mathrm{II})$ complexes, these complexes were expected to have different DNA binding activities. Similar to the reported $\mathrm{Ru}(\mathrm{II})$ complexes of phenanthroline and derivatives, ${ }^{1 f} \mathrm{Ru}$ (II) quinonediimine complexes of cyclam are useful potential metallointercalators owing to their intense optical absorptions in the visible region and their relative ease of preparation. The complexes examined in this work are coordinatively saturated and rigid in structure, the ligands are relatively inert to substitution, and the consideration of covalent bonding to DNA can be neglected. These complexes are dications, and hence, the electrostatic component of binding is a constant across the series. It is commonly observed that intercalators first bind with DNA by electrostatic attractions and then undergo intercalation. ${ }^{9}$ By varying

(4) (a) Barton, J. K.; Danishefsky, A. T.; Goldberg, J. M. J. Am. Chem. Soc. 1984, 106, 2172-2176. (b) Tysoe, S. A.; Morgan, R. J.; Baker, A. D.; Strekas, T. C. J. Phys. Chem. 1993, 97, 1707-1711. (c) Barton, J. K.; Goldberg, J. M.; Kumar, C. K.; Turro, N. J. J. Am. Chem. Soc. 1986, 108, 2081-2088. (d) Kumar, C. V.; Barton, J. K.; Turro, N. J. J. Am. Chem. Soc. 1985, 107, 5518-5523. (e) Liu, H.-Q.; Peng, S.M.; Che, C.-M. J. Chem. Soc., Chem. Commun. 1995, 509-510. (f) Liu, H.-Q.; Cheung, T.-C.; Peng, S.-M.; Che, C.-M. J. Chem. Soc., Chem. Commun. 1995, 1787-1788. (g) Liu, H.-Q.; Cheung, T.-C.; Che, C.-M. J. Chem. Soc., Chem. Commun. 1996, 1039-1040.

(5) (a) Kimura, E.; Bu, X.; Shionoya, M.; Wada, S.; Maruyama, S. Inorg. Chem. 1992, 31, 4542-4546. (b) Kimura, E.; Kurogi, Y.; Takahashi, T. Inorg. Chem. 1991, 30, 4117-4121. (c) Kimura, E.; Wada, S.; Shionoya, M.; Okazaki, Y. Inorg. Chem. 1994, 33, 770-778. (d) Bu, X. H.; Chen, Y. T.; Shionoya, M.; Kimura, E. Polyhedron 1994, 13, 325-331.

(6) (a) Kimura, E.; Sakonaka, A.; Nakamoto, M. Biochim. Biophys. Acta 1981, 678, 172-179. (b) Kodama, M.; Koibke, T.; Mahatma, A. B.; Kimura, E. Inorg. Chem. 1991, 30, 1270-1273. (c) Kimura, E.; Kitamura, H.; Ohtani, K.; Koike, T. J. Am. Chem. Soc. 2000, 122, 4668-4677. (d) Kikuta, K.; Murata, M.; Katsube, N.; Koike, T.; Kimura, E. J. Am. Chem. Soc. 1999, 121, 5426-5436.

(7) Belser, P.; von Zelewsky, A.; Zehnder, M. Inorg. Chem. 1981, 20, 3098-3103.

(8) Che, C.-M.; Kwong, S.-S.; Poon, C.-K.; Lai, T.-F.; Mak, T.-C. Inorg. Chem. 1985, 24, 1359-1363.

(9) Barcelo, F.; Barcelo, I.; Gavilanes, F.; Ferragut, J. A.; Yanovich, S.; Gonzalez-Ros, J. M. Biochim. Biophys. Acta 1986, 884, 172-181. the intercalating ligands and comparing the binding parameters along the series, the effects of altering the surface area for intercalation can be investigated.

\section{Experimental Section}

$\mathrm{RuCl}_{3} \cdot 3 \mathrm{H}_{2} \mathrm{O}$ and ligands were purchased from Aldrich Chemical Co. Calf-thymus DNA (ctDNA) was purchased from Sigma Chemical Co. and purified before use by the method reported by Sambrook et al. ${ }^{10}$ Polynucleotides, [poly $\left.(\mathrm{dG}-\mathrm{dC})\right]_{2}$ and [poly(dAdT) $]_{2}$ (Sigma Chemical Co.), are used as received without further purification. Synthetic oligonucleotides 33 base pairs long dsDNA (33-bp DNA) and 140-bp fluorescein isothiocyanate-labeled dsDNA (FITC-dsDNA) were purchased from DNAgency (Pennsylvania) and Great American Gene Company (California), respectively. Other chemicals are of reagent grade and used as received. All experiments were carried out in aerated Tris buffer solutions (5 $\mathrm{mM}$ Tris, $50 \mathrm{mM} \mathrm{NaCl}, \mathrm{pH}$ 7.2), except stated otherwise. Elemental analyses were done by National Taiwan University.

cis-[ $\mathrm{Ru}$ (cyclam) $\left.\mathrm{Cl}_{2}\right] \mathrm{Cl}$ was synthesized by methods described in ref 11. Complexes and ligands were characterized by IR, NMR, and mass spectroscopy. FT-IR spectra were taken on a Perkin-Elmer 1600 series FTIR spectrophotometer. NMR measurements were made using a Bruker DPX 500 NMR spectrometer. Mass spectra were obtained on a Finnigan MAT95 mass spectrometer.

[Ru(cyclam)(bqdi)]( $\left.\mathbf{Z n C l}_{4}\right)$, 1. cis-[Ru(cyclam) $\left.\mathrm{Cl}_{2}\right] \mathrm{Cl}(0.408 \mathrm{~g}$, $1 \mathrm{mmol}$ ) was stirred with several pieces of amalgamated zinc in $\mathrm{H}_{2} \mathrm{O}(50 \mathrm{~mL})$ under a nitrogen atmosphere for $1 \mathrm{~h}$. $o$-Phenylenediamine $(0.106 \mathrm{~g}, 1 \mathrm{mmol})$ dissolved in $\mathrm{MeOH}(10 \mathrm{~mL})$ was added to the solution. After $2 \mathrm{~h}$, a clear and pale yellow solution was obtained, and then, the solution was exposed to air for several minutes and unreacted zinc residues were filtered off. In the meantime, the solution turned deep red. After addition of excess $\mathrm{ZnCl}_{2}$ and $\mathrm{LiCl}$, the solution was reduced to several milliliters, and red ppt was filtered off and washed with $\mathrm{CHCl}_{3}$. The crude product could be recrystallized from $\mathrm{DMF} / \mathrm{Et}_{2} \mathrm{O}$, and deep red crystals were obtained (yield, 60\%): ${ }^{1} \mathrm{H}$ NMR $\left(\mathrm{D}_{2} \mathrm{O}, 500 \mathrm{MHz}\right) \delta / \mathrm{ppm} 11.74$ $(2 \mathrm{H}, \mathrm{s}, \mathrm{NH}$ of bqdi); 7.27 and 6.85 ( $4 \mathrm{H}$, aromatic $\mathrm{H}$ of bqdi); 5.22 $(4 \mathrm{H}, \mathrm{br}, \mathrm{NH}$ of cyclam); 3.50, 3.32, 3.10, 2.49, 2.41, 2.21, 1.98, $1.74\left(20 \mathrm{H}, \mathrm{CH}_{2}\right.$ of cyclam); ${ }^{13} \mathrm{C}$ NMR $\left(\mathrm{D}_{2} \mathrm{O}, 500 \mathrm{MHz}\right) \delta / \mathrm{ppm}$ 170.9 ( $\alpha$-diimine $\mathrm{C}=\mathrm{N}$ of bqdi); 125.4 and 120.9 (aromatic ring of bqdi); 56.7, 53.5, 51.1, 49.4, and $24.9\left(\mathrm{CH}_{2}\right.$ of cyclam). Anal. Calcd (\%): C, 31.26; H, 4.92; N, 13.67. Found (\%): C, 31.15; H, $5.08 ; \mathrm{N}, 13.44$.

$[\mathrm{Ru}(\mathrm{cyclam})(\mathbf{n q d i})]\left(\mathrm{ClO}_{4}\right)_{2}, 2$. The synthesis and purification of $\mathbf{2} \cdot\left(\mathrm{ClO}_{4}\right)_{2}$ were similar to those of $\mathbf{1} \cdot \mathrm{ZnCl}_{4}$, except that 2,3-naphthalenediamine and $\mathrm{LiClO}_{4}$ were used instead of $o$ phenylenediamine and $\mathrm{ZnCl}_{2}$ and $\mathrm{LiCl}$, respectively: $\mathrm{IR}(\mathrm{KBr})$ for 2. $\left(\mathrm{ClO}_{4}\right)_{2} 3182(\mathrm{w})$ and $3130(\mathrm{~m})(v \mathrm{NH}) ; 2925(\mathrm{w})$ and $2900(\mathrm{w})$ $(\nu \mathrm{CH}) ; 1443(\mathrm{~m}) ; 1140,1111$, and $1084(\mathrm{~s}, \mathrm{~b})\left(\nu \mathrm{ClO}_{4}\right) ;{ }^{1} \mathrm{H}$ NMR for $2 \cdot\left(\mathrm{ClO}_{4}\right)_{2}\left(\mathrm{CD}_{3} \mathrm{CN}, 300 \mathrm{MHz}\right) \delta / \mathrm{ppm} 10.81-10.78(2 \mathrm{H}, \mathrm{d}, \mathrm{NH}$ of nqdi); $7.31-7.20(\mathrm{~m})$ and $5.19-5.15(\mathrm{~d})(6 \mathrm{H}$, aromatic $\mathrm{H}$ of nqdi); 4.27 (4H, br, NH of cyclam); 3.41-3.27, 3.32-3.05, 2.64-2.58, $2.39-2.07,1.77-1.68\left(20 \mathrm{H}, \mathrm{CH}_{2}\right.$ of cyclam); $627(\mathrm{~ms}) \mathrm{cm}^{-1} ; \mathrm{FAB}-$ (NBA, $m / z$ ) for 2,557 for $\left[\mathrm{Ru}\left(\mathrm{C}_{10} \mathrm{H}_{24} \mathrm{~N}_{4}\right)\left(\mathrm{C}_{10} \mathrm{H}_{8} \mathrm{~N}_{2}\right)\right] \cdot\left(\mathrm{ClO}_{4}\right)$ and 456 for $\left[\mathrm{Ru}\left(\mathrm{C}_{10} \mathrm{H}_{24} \mathrm{~N}_{4}\right)\left(\mathrm{C}_{10} \mathrm{H}_{8} \mathrm{~N}_{2}\right)\right]-\mathrm{H}$. Anal. Calcd (\%) for $\mathbf{2}$. $\left(\mathrm{ClO}_{4}\right)_{2}: \mathrm{C}, 36.59 ; \mathrm{H}, 4.91 ; \mathrm{N}, 12.80$. Found (\%): C, 36.38; H, 5.12; N, 12.44 (yield, 60\%).

$[\mathrm{Ru}(\mathrm{cyclam})(\mathrm{phi})]\left(\mathrm{ClO}_{4}\right)_{2}, 3$. The synthesis and purification of 3. $\left(\mathrm{ClO}_{4}\right)_{2}$ were similar to those of $\mathbf{1} \cdot \mathrm{ZnCl}_{4}$, except that 9,10 -

(10) In Molecular Cloning, A Laboratory Manual, 2nd Ed.; Sambrook, J., Fritsch, E. F., Maniatis, T., Eds.; Cold Spring Harbor Laboratory Press: New York, 1989.

(11) You, Y.-S. Ph.D. Thesis, National Taiwan University, 1998.

3162 Inorganic Chemistry, Vol. 41, No. 12, 2002 
phenanthrenediamine and $\mathrm{LiClO}_{4}$ were used instead of $o$-phenylenediamine and $\mathrm{ZnCl}_{2}$ and $\mathrm{LiCl}$, respectively: $\mathrm{IR}(\mathrm{KBr})$ for $\mathbf{3} \cdot$ $\left(\mathrm{ClO}_{4}\right)_{2}$ 3112(w) and 3060(w) $(\nu \mathrm{NH}) ; 2967(\mathrm{w})$ and 2925(w) (varomatic $\mathrm{H}) ; 1596(\mathrm{w}), 1493(\mathrm{~m})(\nu \mathrm{C}=\mathrm{N}), 1086(\mathrm{~b})\left(\nu \mathrm{ClO}_{4}\right), 756-$ (m), 626(m) cm ${ }^{-1}$; ${ }^{1} \mathrm{H}$ NMR $\left(\mathrm{CD}_{3} \mathrm{CN}, 200 \mathrm{MHz}\right)$ for $3 \cdot\left(\mathrm{ClO}_{4}\right)_{2}$ $\delta / \mathrm{ppm} 11.48(2 \mathrm{H}, \mathrm{s}, \mathrm{NH}$ of phi); 8.99, 8.50, and $7.75(8 \mathrm{H}$, aromatic $\mathrm{H}$ of phi); 5.03 (4H, br, NH of cyclam); 3.77-3.60, 3.48-3.36, 2.61-2.40, 2.35-2.28, $2.08\left(20 \mathrm{H}, \mathrm{CH}_{2}\right.$ of cyclam); FAB(NBA, $m / z$ ) for 3, 607 for $\mathrm{Ru}\left(\mathrm{C}_{10} \mathrm{H}_{24} \mathrm{~N}_{4}\right)\left(\mathrm{C}_{14} \mathrm{H}_{10} \mathrm{~N}_{2}\right)\left(\mathrm{ClO}_{4}\right)_{2}$ and 506 for $\mathrm{Ru}\left(\mathrm{C}_{10} \mathrm{H}_{24} \mathrm{~N}_{4}\right)\left(\mathrm{C}_{14} \mathrm{H}_{10} \mathrm{~N}_{2}\right)-\mathrm{H}$. Anal. Calcd (\%) for 3-( $\left.\mathrm{ClO}_{4}\right)_{2}$ : C, 40.80; H, 4.85; N, 11.89. Found (\%): C, 40.74; H, 4.96; N, 11.75 (yield, 40\%).

Absorption Measurements. All absorption spectra were recorded on a Perkin-Elmer Lambda 19 UV-vis-NIR spectrophotometer equipped with a Peltier temperature programmer PTP-6. The absorption titration was performed by keeping the concentration of metal complex constant, while varying the nucleic acid concentration. The absorbance at a selected wavelength was recorded after each addition of ctDNA. The absorption spectra of the complexes in the absence and in the presence of a polyanion, sodium dodecyl sulfate micelles, were recorded to investigate their interactions with the polyanionic phosphate backbone.

DNA Melting Studies. UV melting study is a technique to evaluate the stability of a DNA double helix. UV melting studies were carried out using a Perkin-Elmer Lambda 19 UV-vis spectrophotometer equipped with a Peltier temperature programmer PTP-6. 33-bp DNA and ctDNA were used in this study. Solutions of DNA in the absence and presence of $\mathrm{Ru}(\mathrm{II})$ complex with a [complex]/[DNA-base pair] of 1:1 were prepared in $5 \mathrm{mM}$ Tris, $50 \mathrm{mM} \mathrm{NaCl}, \mathrm{pH}$ 7.2. The temperature of the solution was increased at $1{ }^{\circ} \mathrm{C} \mathrm{min}-1$, and the absorbance at $260 \mathrm{~nm}$ was continuously monitored.

Viscosity Experiments. Rodlike DNA samples approximately $200 \mathrm{bp}$ in length were prepared by sonication (ref 12) for viscosity measurements. The method used by Suh and Chaires ${ }^{13}$ was employed in this study. Viscosity experiments were performed on a Cannon-Manning Semi-Micro Viscometer, immersed in a thermostated water bath maintained at $27^{\circ} \mathrm{C}$. Titrations of ligand were carried out by the addition of small volumes of concentrated stock solutions to the DNA sample in BPE buffer (6 $\mathrm{mM} \mathrm{Na}_{2} \mathrm{HPO}_{4}, 2$ $\mathrm{mM} \mathrm{NaH}{ }_{2} \mathrm{PO}_{4}$, and $1 \mathrm{mM} \mathrm{Na} 2 \mathrm{EDTA}, \mathrm{pH}$ 7.0) in the viscometer. Solutions in the viscometer were mixed by bubbling nitrogen through the solution. DNA concentrations of approximately $5 \times$ $10^{-4} \mathrm{M}$ (in base pairs) were used. Relative viscosity for DNA in either the presence or absence of ligand was calculated from the relation

$$
\eta=\left(t-t_{\mathrm{o}}\right) / t_{\mathrm{o}}
$$

where $t$ is the observed flow time of the DNA containing solution and $t_{\mathrm{o}}$ is the flow time of buffer alone.

Gel Mobility Shift Assay. 33-bp DNA was mixed with complexes 1, 2, and $\mathbf{3}$ at [complex]/[bp] of 1.21:1. In addition, a concentration dependence experiment was also conducted for $\mathbf{3}$ with [complex]/[bp] ranging from $0.30: 1$ to $1.21: 1$. The mixtures were incubated at room temperature for $5 \mathrm{~min}$ before analyzing by gel electrophoresis (Mini-PROTEAN II Cell, BIO-RAD). Elongated DNA molecules were differentiated from the originals by moving in a $20 \%(\mathrm{w} / \mathrm{v})$ polyacrylamide gel. After electrophoresis, DNA bands were visualized by EB staining.

(12) Chaires, J. B.; Dattagupta, N.; Crothers, D. M. Biochemistry 1982, 21, 3933-3940

(13) Suh, D.; Chaires, J. B. Bioorg. Med. Chem. 1995, 3, 723-728.
FITC-dsDNA of 140-bp was mixed with EB and complexes 1-3. [complex]/[bp] of (5.6:1) was used for $\mathbf{1}-\mathbf{3}$. Another ratio (1.0:1) was used for EB and 3. Similar to the case of 33-bp DNA, the mixtures were also incubated before analyzing by gel electrophoresis.

Restriction Endonuclease Fragmentation Assay. Digestion of a plasmid, pDR2 (10.7 kb), with a restriction enzyme, ApaI (Boehringer Mannheim), was done by mixing the DNA $\left(3.0 \times 10^{-4}\right.$ $M$ in base pairs) in $1 \times$ SuRE/Cut Buffer A (Boehringer Mannheim) with ApaI ( $1 \mathrm{unit} / \mu \mathrm{L}$ ), followed by incubation at $37{ }^{\circ} \mathrm{C}$ for $1 \mathrm{~h} .{ }^{10}$ A mixture of compound and a plasmid, pDR2 (10.7 kbp, $3.0 \times$ $10^{-4} \mathrm{M}$ in base pairs), in digestion buffer was first incubated at room temperature for $5 \mathrm{~min}$ before the addition of ApaI. Two controls of pDR2 in the absence and presence of ApaI were also prepared. After digestion, the samples were analyzed by electrophoresis.

Circular Dichroism (CD). CD was run on a Jasco J-720 spectropolarimeter at $0.2 \mathrm{~nm} / \mathrm{s}$ scanning speed, using $5 \mathrm{~cm}$ path quartz cuvettes. The induced $\mathrm{CD}$ spectra of the $\mathrm{Ru}(\mathrm{II})$ complexes in the absence and in the presence of ctDNA, polynucleotides [poly$(\mathrm{dG}-\mathrm{dC})]_{2}$ or $[\text { poly }(\mathrm{dA}-\mathrm{dT})]_{2}$ were recorded in Tris buffer at room temperature.

Cytotoxicity Test (Sulforhodamine B (SRB) Drug Screening Assay). The parental KB-3-1 cell line and its multidrug-resistant subclone KB-V1 cell line were generously provided by Dr. Michael Gottesman, National Institute of Health, Bethesda, Maryland. ${ }^{14} \mathrm{~KB}$ $\mathrm{V} 1$ cells were derived from KB-3-1 cells by a series of stepwise selections in vinblastin, and maintained in the presence of $1 \mu \mathrm{g}$ $\mathrm{mL}^{-1}$ vinblastin.

The cytotoxicities of the metal complexes were determined by the standard SRB drug screening assay, ${ }^{15}$ and dose response curves of drug effects on cell survival were constructed.

Apoptosis Assay: Acridine Orange/Ethidium Bromide (AO/EB) Staining. On the basis of the difference in membrane integrity between necrotic and apoptotic cells, a staining method utilizing $\mathrm{AO}$ and $\mathrm{EB}$ was used. ${ }^{16} \mathrm{AO}$ can pass through cell membrane, but EB cannot. Under fluorescence microscope, live cells appear green. Necrotic cells stain red but have a nuclear morphology resembling that of viable cells. Apoptotic cells appear green, and morphological changes such as cell blebbing and formation of apoptotic bodies will be observed.

Cell cultures of a monolayer of KB-3-1 cells were incubated in the absence and in the presence of either $\mathbf{1}, \mathbf{2}$, or $\mathbf{3}$ at concentration equal to $\mathrm{IC}_{30}$ at $37{ }^{\circ} \mathrm{C}$ and $5 \% \mathrm{CO}_{2}$ for $72 \mathrm{~h}$. After $72 \mathrm{~h}$, each cell culture was stained with AO/EB solution $(2 \mu \mathrm{g} / \mathrm{mL}$ AO, $2 \mu \mathrm{g} / \mathrm{mL}$ EB). Samples were observed under a laser confocal microscope (Zeiss Axiovert 100M).

Apoptosis Assay: DNA Ladder Analysis. The cell line tested was KB-3-1. Cells were cultured at a concentration of approximately $2 \times 10^{5}$ cells $/ \mathrm{mL}$. Compounds were added to the cultures at their $\mathrm{IC}_{30}, \mathbf{1}\left(7.1 \times 10^{-4} \mathrm{M}\right), \mathbf{2}\left(4.1 \times 10^{-4} \mathrm{M}\right)$, and $\mathbf{3}\left(1.4 \times 10^{-4} \mathrm{M}\right)$. Flasks of cells were irradiated with $60 \mathrm{~mJ} / \mathrm{cm}^{2} \mathrm{UV}-\mathrm{C}$ using a Stratalinker 2400 (Stratagene, La Jolla, CA) to induce apoptosis. An untreated sample was regarded as a negative control. After

(14) (a) Akiyama, S. I.; Fojo, A.; Hanover, J. A.; Gottesman, M. M.; Pastan, I. Somatic Cell Mol. Genet. 1985, 11, 117-126. (b) Shen, D. W.; Cardarelli, C.; Cornwell, M.; Gottesman, M. M.; Hwang, J.; Ishii, S.; Pastan, I.; Richert, N. J. Biol. Chem. 1986, 261, 7762-7770.

(15) Skehan, P.; Storeng, R.; Scudiero, D.; Monks, D. A.; McMahon, J.; Vistica, D.; Warren, J. T.; Bokesch, H.; Kenney, S.; Boyd, M. R. J. Natl. Cancer Inst. 1990, 82, 1107-1112.

(16) In Cells: A laboratory manual; Spector, D. L., Goldman, R. D., Leinwand, L. A., Eds.; Cold Spring Harbor Laboratory Press: New York, 1998, Vol. 1, Chapter 15. 
Chan et al.

(1) $\mathrm{L}$

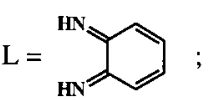

(2) $\mathrm{L}$

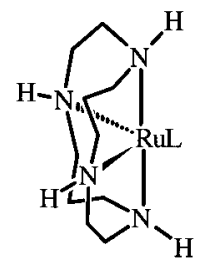

(3) $\mathrm{L}=$

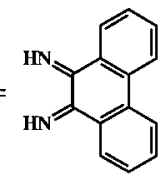

Figure 1. Structures of $\mathbf{1}, \mathbf{2}$, and 3 .

treatment, all the cultures were incubated at $37^{\circ} \mathrm{C}, 5 \% \mathrm{CO}_{2}$. Cells were collected at different time points, 6, 12, and $24 \mathrm{~h}$. Their genomic DNA was extracted according to ref 10 and analyzed by gel electrophoresis.

\section{Results and Discussion}

The reactions of synthesizing $\mathbf{1} \cdot \mathrm{ZnCl}_{4}, \mathbf{2} \cdot\left(\mathrm{ClO}_{4}\right)_{2}$, and $\mathbf{3} \cdot$ $\left(\mathrm{ClO}_{4}\right)_{2}$ were generally described. cis-[ $\mathrm{Ru}^{\mathrm{III}}($ cyclam $\left.) \mathrm{Cl}_{2}\right] \mathrm{Cl}$ first reacted with $o$-phenylenediamine, 2,3-naphthalenediamine, or 9,10-phenanthrenediamine, in the presence of amalgamated zinc. In the reaction, $\mathrm{Ru}(\mathrm{III})$ was reduced to be $\mathrm{Ru}(\mathrm{II})$. Then, the reaction mixtures were subjected to air oxidation and oxido-hydrogenation. The diamine ligands were all oxidized to be diimine ligands: bqdi, nqdi, and phi, but the oxidation state of the metal center Ru(II) was not changed. The overall reaction was a metal reduction-ligand oxidation. Because the oxidized quinonediimine is a $\pi$-acceptor and it can stabilize the lower oxidation state of $\mathrm{Ru}(\mathrm{II})$ by back-bonding, the reaction can be carried out. The structures of the $\mathrm{Ru}(\mathrm{II})$ quinonediimine complexes $\mathbf{1}, \mathbf{2}$, and 3 are shown in Figure 1.

$\mathrm{X}$-ray Characterization. X-ray crystal structures of $\mathbf{1} \cdot \mathrm{ZnCl}_{4}$ and $\mathbf{3} \cdot\left(\mathrm{ClO}_{4}\right)_{2}$ are shown in Figure 2. Crystallographic data appear in Tables 1 and 2. The structures of 1 and 3 reveal that they both consist of a six-coordinated $\mathrm{Ru}$ (II) ion surrounded by four nitrogen atoms of the folded macrocyclic cyclam ligands with bqdi and phi occupying the cis site of the complexes, and the former has a counteranion of $\mathrm{ZnCl}_{4}{ }^{2-}$ probably because of the reaction of $\mathrm{ZnCl}_{2}$ and $\mathrm{LiCl}$. Both complexes clearly show that the original planar macrocyclic cyclam is bent into a folded conformation, which is similar to that of $\left[\mathrm{Fe}\left(\mathrm{C}_{18} \mathrm{H}_{18} \mathrm{~N}_{6}\right)\right.$ $\left.\left(\mathrm{C}_{12} \mathrm{H}_{8} \mathrm{~N}_{2}\right)\right]\left(\mathrm{ClO}_{4}\right)_{2} \cdot{ }^{17}$ The $\mathrm{Ru}-\mathrm{N}_{\mathrm{av}}$ are 1.987(3) and 1.998(8) $\AA$ for $\mathbf{1}$ and $\mathbf{3}$, respectively, which are comparable to those values of $2.017(8) \AA$ in $\left[\mathrm{Ru}(\mathrm{bpy})_{2}(\mathrm{bqdi})\right]^{2+}$ (bpy $=$ bipyridine $)^{18}$ and of $2.006(4) \AA$ in $\left[\mathrm{Ru}(\mathrm{bpy})_{2}(\mathrm{phi})\right]^{2+},{ }^{1 \mathrm{f}}$ regardless of distinct $\pi$-acidity properties between cyclam and bpy ligands. The bond parameters of bqdi and phi are also similar to those of $\left[\mathrm{Ru}(\mathrm{bpy})_{2}(\mathrm{bqdi})\right]^{2+}$ and $\left[\mathrm{Ru}(\mathrm{bpy})_{2^{-}}\right.$ (phi) $]^{2+}$, indicating that both bqdi and phi are in imine forms which are oxidized from the deprotonated diamine (dianion forms) as those of previous works. ${ }^{19}$ The near planarity of bqdi and phi ligands makes these complexes potential DNA intercalators. Though the X-ray crystal structure of $\mathbf{2} \cdot\left(\mathrm{ClO}_{4}\right)_{2}$

(17) You, Y.-S.; Peng, S.-M. Inorg. Chim. Acta 1992, 192, 9-11.

(18) Pyle, A. M.; Barton, J. K. Inorg. Chem. 1987, 26, 3820-3823.
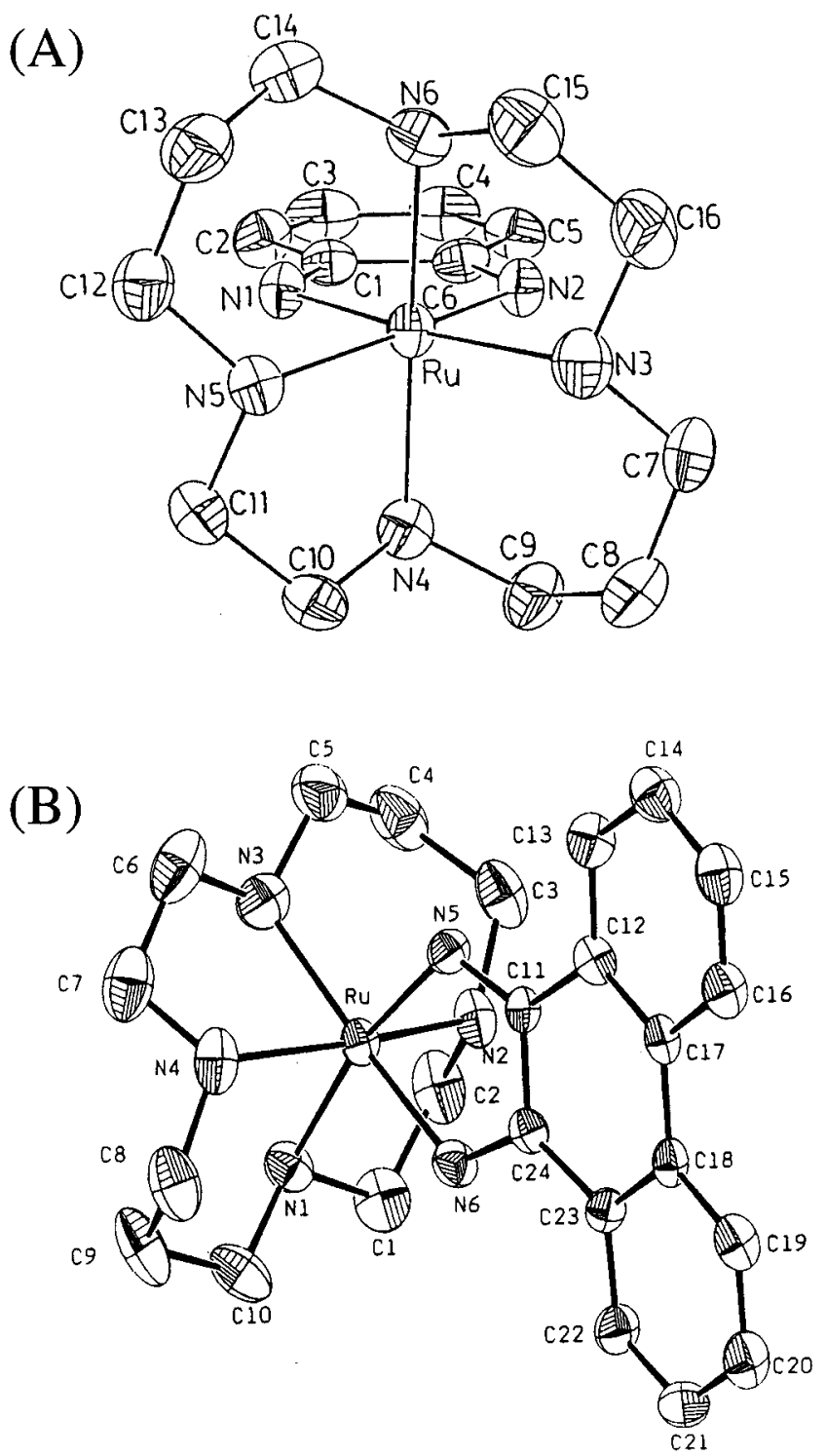

Figure 2. (A) Perspective view of $\mathbf{1}$ cation. Selected bond distances $(\AA)$ and angles (deg): $\mathrm{Ru}-\mathrm{N}(1)=1.985(3), \mathrm{Ru}-\mathrm{N}(2)=1.989(3), \mathrm{Ru}-\mathrm{N}(3)$ $=2.136(3), \mathrm{Ru}-\mathrm{N}(4)=2.112(3), \mathrm{Ru}-\mathrm{N}(5)=2.132(3), \mathrm{Ru}-\mathrm{N}(6)=$ 2.113(3), $\mathrm{N}(2)-\mathrm{C}(6)=1.334(5), \mathrm{N}(1)-\mathrm{C}(1)=1.328(5), \mathrm{C}(6)-\mathrm{C}(5)=$ $1.428(5), \mathrm{C}(5)-\mathrm{C}(4)=1.532(6), \mathrm{C}(1)-\mathrm{C}(2)=1.424(5), \mathrm{C}(2)-\mathrm{C}(3)=$ 1.354(6), $\mathrm{C}(1)-\mathrm{C}(6)=1.429(5), \mathrm{C}(3)-\mathrm{C}(4)=1.406(7), \mathrm{N}(1)-\mathrm{Ru}-\mathrm{N}(2)$ $=77.89(12), \mathrm{N}(1)-\mathrm{Ru}-\mathrm{N}(5)=93.41(12), \mathrm{N}(2)-\mathrm{Ru}-\mathrm{N}(3)=94.14(13)$, $\mathrm{N}(3)-\mathrm{Ru}-\mathrm{N}(5)=94.65(12), \mathrm{N}(4)-\mathrm{Ru}-\mathrm{N}(6)=167.02(12)$. (B) Perspective view of 3 cation. Selected bond distances $(\AA)$ and angles (deg): $\mathrm{Ru}-\mathrm{N}(1)=2.141(8), \mathrm{Ru}-\mathrm{N}(2)=2.120(9), \mathrm{Ru}-\mathrm{N}(3)=2.094(9)$ $\mathrm{Ru}-\mathrm{N}(4)=2.117(9), \mathrm{Ru}-\mathrm{N}(5)=2.017(8), \mathrm{Ru}-\mathrm{N}(6)=1.978(8), \mathrm{N}(5)-$ $\mathrm{C}(11)=1.316(12), \mathrm{N}(6)-\mathrm{C}(24)=1.332(13), \mathrm{C}(11)-\mathrm{C}(24)=1.413(14)$, $\mathrm{C}(11)-\mathrm{C}(12)=1.448(13), \mathrm{C}(23)-\mathrm{C}(24)=1.406(7), \mathrm{N}(1)-\mathrm{Ru}-\mathrm{N}(2)=$ $82.1(4), \mathrm{N}(1)-\mathrm{Ru}-\mathrm{N}(6)=92.2(3), \mathrm{N}(5)-\mathrm{Ru}-\mathrm{N}(6)=76.6(3), \mathrm{N}(2)-$ $\mathrm{Ru}-\mathrm{N}(4)=166.7(3), \mathrm{N}(1)-\mathrm{Ru}-\mathrm{N}(3)=94.5(3), \mathrm{N}(2)-\mathrm{Ru}-\mathrm{N}(5)=$ 95.8(3), $\mathrm{N}(2)-\mathrm{Ru}-\mathrm{N}(3)=90.7(4)$.

has not been solved by X-ray crystallography, it is expected to have a similar structure to those of $\mathbf{1} \cdot \mathrm{ZnCl}_{4}$ and $\mathbf{3} \cdot\left(\mathrm{ClO}_{4}\right)_{2}$.

Electronic Transitions. For 1, 2, and 3, their UV-vis absorption spectra in aqueous solutions all display intense

(19) (a) Chern, S.-S.; Lee, G.-H.; Peng, S.-M. J. Chem. Soc., Chem Commun. 1994, 1645-1646. (b) Chern, S.-S.; Liaw, M.-C.; Peng, S.M. J. Chem. Soc., Chem. Commun. 1993, 359-361. (c) Peng, S.-M.; Chen, C.-T.; Liaw, D.-S.; Chen, C.-I.; Wang, Y. Inorg. Chim. Acta 1985, 101, L31-L33. 


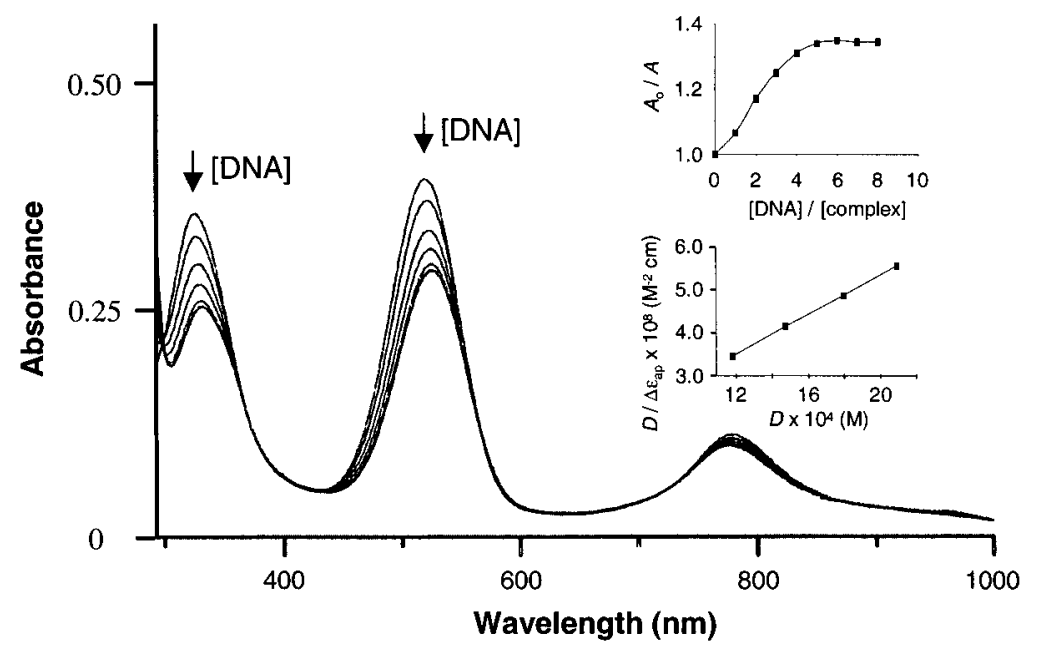

Figure 3. UV-vis spectra of $3\left(2.86 \times 10^{-5} \mathrm{M}\right)$ in Tris buffer solution with increasing concentration of ctDNA $\left(0-1.79 \times 10^{-4} \mathrm{M}\right.$ in base pairs $)$ at room temperature. Inset: plots of $A_{0} / A$ vs [DNA]/[complex] and $D / \Delta \epsilon_{\text {ap }}$ vs $D$. Absorbance was monitored at $519 \mathrm{~nm}$.

Table 1. Crystallographic Data for 1

\begin{tabular}{ll}
\hline formula $\mathrm{C}_{16} \mathrm{H}_{31} \mathrm{~N}_{6} \mathrm{Cl}_{4} \mathrm{O}_{0.5} \mathrm{RuZn}$ & $D_{\text {calcd }}=1.758 \mathrm{~g} \mathrm{~cm}^{-3}$ \\
$\mathrm{fW}=623.72$ & $\mu=9.30 \mathrm{~cm}^{-1}$ \\
monoclinic & $F(000)=1119.79$ \\
space group $P 21 / c$ & cryst dimensions $0.40 \times 0.40 \times 0.35 \mathrm{~mm}^{3}$ \\
$a=12.965(6) \AA$ & no. unique reflns $=4125$ \\
$b=10.031(4) \AA$ & no. reflns measured $=4125$ \\
$c=18.302(5) \AA$ & no. reflns with $I>2 \sigma(I)=3289$ \\
$\beta=98.16(3)^{\circ}$ & $R_{\mathrm{F}}=0.042$ \\
$V=2356.0(16)^{3}$ & $R_{\mathrm{W}}=0.028$ \\
$Z=4$ & $\mathrm{GOF}=1.73$
\end{tabular}

Table 2. Crystallographic Data for 3

\begin{tabular}{ll}
\hline formula $\mathrm{C}_{24} \mathrm{H}_{34} \mathrm{~N}_{6} \mathrm{Cl}_{2} \mathrm{O}_{8} \mathrm{Ru}$ & $D_{\text {calcd }}=1.620 \mathrm{~g} \mathrm{~cm}^{-3}$ \\
fW $=706.54$ & $\mu=8.650 \mathrm{~cm}^{-1}$ \\
monoclinic & $F(000)=1448$ \\
space group $P 21 / n$ & cryst dimensions $0.15 \times 0.15 \times 0.60 \mathrm{~mm}^{3}$ \\
$a=13.333(4) \AA$ & no. unique reflns $=3770$ \\
$b=14.54160(0) \AA$ & no. reflns measured $=3770$ \\
$c=16.284(8) \AA$ & no. of reflns with $I>2 \sigma(I)=2568$ \\
$\beta=113.42(3)^{\circ}$ & $R_{\mathrm{F}}=0.058$ \\
$V=2897.0(17)^{3}$ & $R_{\mathrm{W}}=0.062$ \\
$Z=4$ & GOF $=2.44$ \\
& weights scheme $\left(1 / \sigma_{2}\right)(\mathrm{FO})$
\end{tabular}

Table 3. UV-Visible Spectroscopic Data of Ru(II) Complexes in Degassed Aqueous Solution at Room Temperature

\begin{tabular}{cc}
\hline complex & absorption $\lambda_{\max } / \mathrm{nm}\left(\epsilon / \mathrm{mol}^{-1} \mathrm{~cm}^{-1}\right)$ \\
\hline $\mathbf{1}$ & $476\left(1.02 \times 10^{4}\right), 285(\mathrm{sh})\left(3.49 \times 10^{3}\right), 252\left(9.70 \times 10^{3}\right)$, \\
$\mathbf{2}$ & $511\left(9.68 \times 10^{4}\right), 437(\mathrm{sh})\left(3.92 \times 10^{3}\right), 272\left(4.67 \times 10^{3}\right)$, \\
& $232\left(9.08 \times 10^{3}\right), 204\left(1.64 \times 10^{4}\right)$ \\
$\mathbf{3}$ & $778\left(4.08 \times 10^{3}\right), 519\left(1.37 \times 10^{4}\right), 325\left(1.23 \times 10^{4}\right)$, \\
& $259\left(2.06 \times 10^{4}\right), 213\left(2.45 \times 10^{4}\right)$
\end{tabular}

absorbance in an extensive wavelength range. The spectroscopic data obtained experimentally are summarized in Table 3.

The $\mathrm{Ru}(\mathrm{II})$ complexes studied here are all nonemissive both in solid state and in degassed aqueous solution at room temperature, just like the $\mathrm{Ru}(\mathrm{II})$ quinonediimine complexes reported in the literature. ${ }^{1 f, 20}$

(20) (a) David, S. S.; Barton, J. K. J. Am. Chem. Soc. 1993, 115, 29842985. (b) Pyle, A. M.; Chiang, M.; Barton, J. K. Inorg. Chem. 1990 29, 4487-4495.
With reference to the previous work for $\left[\mathrm{Ru}^{\mathrm{II}}(\mathrm{cyclam})\right.$ (bpy) $]^{2+}{ }^{8} \mathrm{Ru}$ (II) complexes with $o$-quinodiimine ligands, ${ }^{7}$ it is reasonable to assign the bands at high energy (200$300 \mathrm{~nm})$ to intraligand $\pi-\pi^{*}$ transitions and the long wavelength (300 to $800 \mathrm{~nm}$ ) transition to MLCT, that is, the transition to a $\pi^{*}$ orbital of the $o$-quinonediimine ligand for the $\mathrm{Ru}(\mathrm{II})$ complexes studied here.

DNA Binding Studies. Because 1-3 are all nonemissive, fluorescence titrations cannot be carried out on these complexes. Their DNA binding constants were determined by the absorption titration experiments.

Absorption titrations for the Ru(II) complexes with ctDNA were performed in Tris buffer solution at room temperature. No significant spectral change was observed for $\mathbf{1}$ with ctDNA, suggesting that there was no binding interaction affecting electronic transitions. Although small changes in the absorption spectrum of $\mathbf{2}$ with addition of ctDNA were observed, it was difficult to get an accurate quantitative result with these spectral data.

In contrast to the spectra of the two complexes described previously, the absorption spectra of $\mathbf{3}$ with ctDNA show several hypochromisms at 325, 519, and $778 \mathrm{~nm}$ (Figure 3). The hypochromicity at $519 \mathrm{~nm}$ was estimated to be $27 \%$. A red shift $\left(\Delta \lambda_{\max }=6 \mathrm{~nm}\right)$ and two isosbestic points at 566 and $298 \mathrm{~nm}$ were observed. The absorbance at 325, 519 (Figure 3 inset), and $778 \mathrm{~nm}$ reached saturation. In the control experiment using sodium dodecyl sulfate (SDS) instead of DNA, there was no significant spectral difference in the spectra of the $R u($ II) complexes in the absence and in the presence of SDS. It indicated that the absorption spectral changes observed with double-stranded DNA (dsDNA) are not due to electrostatic binding of the cationic metal complex to the polyanionic DNA phosphate backbone. For an intercalator, its intercalating surface is sandwiched tightly between the aromatic, heterocyclic base pairs and stabilized electronically in the helix by $\pi-\pi$ stacking and dipoledipole interactions. Binding commonly results in hypochromism and a shift to longer wavelength of the transition of the intercalated chromophore. ${ }^{21}$ 
Chan et al.

The intrinsic binding constant, $K$, of the metal complex to DNA can be determined from a plot of $D / \Delta \epsilon_{\text {ap }}$ versus $D$ according to Kumar and Asuncion ${ }^{22}$

$$
D / \Delta \epsilon_{\mathrm{ap}}=D / \Delta \epsilon+1 /(\Delta \epsilon \times K)
$$

where $D$ is the concentration of DNA, $\Delta \epsilon_{\text {ap }}=\left|\epsilon_{\mathrm{A}}-\epsilon_{\mathrm{F}}\right|$ in which $\epsilon_{\mathrm{A}}=A_{\text {obs }} /[$ metal complex $]$, and $\Delta \epsilon=\left|\epsilon_{\mathrm{B}}-\epsilon_{\mathrm{F}}\right| . \epsilon_{\mathrm{B}}$ and $\epsilon_{\mathrm{F}}$ correspond to the extinction coefficient of DNA-bound metal complex and free metal complex, respectively.

Because there was no or only small changes in the absorption spectra of $\mathbf{1}$ and $\mathbf{2}$, the DNA affinity constants of the two complexes could not be determined. A plot of $D / \Delta \epsilon_{\text {ap }}$ versus $D$ at $519 \mathrm{~nm}$ (Figure 3 inset) for 3 with ctDNA was made to yield the intrinsic binding constants. ${ }^{4 e}$ The DNA binding constants, $K$, of $\mathbf{3}$ determined at 325 and $519 \mathrm{~nm}$ are $5.3( \pm 0.5) \times 10^{4} \mathrm{M}^{-1}$ and $5.0( \pm 0.8) \times 10^{4} \mathrm{M}^{-1}$, respectively, and they are in good agreement.

Base pair preference of $\mathbf{3}$ upon binding to polynucleotides has been investigated. In the presence of $[\text { poly }(\mathrm{dG}-\mathrm{dC})]_{2}, \mathbf{3}$ displays a large hypochromicity (25\%) and a small red shift $(\Delta \lambda=8 \mathrm{~nm})$ with two isosbestic points at 555 and $299 \mathrm{~nm}$. Similar absorption spectral changes for the interaction of $\mathbf{3}$ with $[\text { poly }(\mathrm{dA}-\mathrm{dT})]_{2}$ were observed: hypochromicity $=29 \%$, a small red shift $\Delta \lambda=6 \mathrm{~nm}$, and two isosbestic points at 567 and $296 \mathrm{~nm}$. The results obtained from the absorption titration for 3 with ctDNA were intermediate between those obtained for $[\text { poly }(\mathrm{dG}-\mathrm{dC})]_{2}$ and $[\mathrm{poly}(\mathrm{dA}-\mathrm{dT})]_{2}$. It suggested that 3 bound to ctDNA at both GC and AT sites, and there was no significant base preference.

Thermodynamic Profile of the Binding of 3 to DNA. The thermodynamic parameters, such as the standard enthalpy and entropy, of the binding of $\mathbf{3}$ to DNA were determined by substituting the experimental data obtained from absorbance titrations and DNA melting studies into van't Hoff's equation (eq 3 ) and the equations of the standard free energy change (eqs 4 and 5). The DNA melting curves of ctDNA in the absence and in the presence of $\mathbf{1}, \mathbf{2}$, and $\mathbf{3}$ are presented in Figure 4A. The melting temperature $\left(T_{\mathrm{m}}\right)$ of ctDNA was found to be $77^{\circ} \mathrm{C}$. In the presence of $\mathbf{1}$ and 2, $T_{\mathrm{m}}$ of ctDNA was raised to 78 and $82^{\circ} \mathrm{C}$, respectively. However, in the presence of $\mathbf{3}$, the absorbance of the mixture gradually increased, and there was no dramatic rise in absorbance as observed in transition from dsDNA to ssDNA. Because $\mathbf{1}$ and $\mathbf{2}$ have no or very weak interaction with DNA, only the thermodynamic profile of the binding of $\mathbf{3}$ to DNA was determined.

The absorption spectra of $\mathbf{3}\left(2.60 \times 10^{-5} \mathrm{M}\right)$ in the absence and presence of ctDNA with a [3]/[DNA-base pair] of (1:1) at $90{ }^{\circ} \mathrm{C}$ are presented in the inset of Figure 4A. Hypochromism and red shift at 313 and $519 \mathrm{~nm}$ were observed. The shape and intensity of $\mathbf{3}$ did not return to that of free metal complex even at $90{ }^{\circ} \mathrm{C}$. The interaction of singlestranded DNA (ssDNA) and $\mathbf{3}$ was also investigated. Addition of saturated amount of ssDNA to a solution of $\mathbf{3}$

(21) Long, E. C.; Barton, J. K. Acc. Chem. Res. 1990, 23, 271-273.

(22) Kumar, C. V.; Asuncion, E. H. J. Am. Chem. Soc. 1993, 115, 85478553.
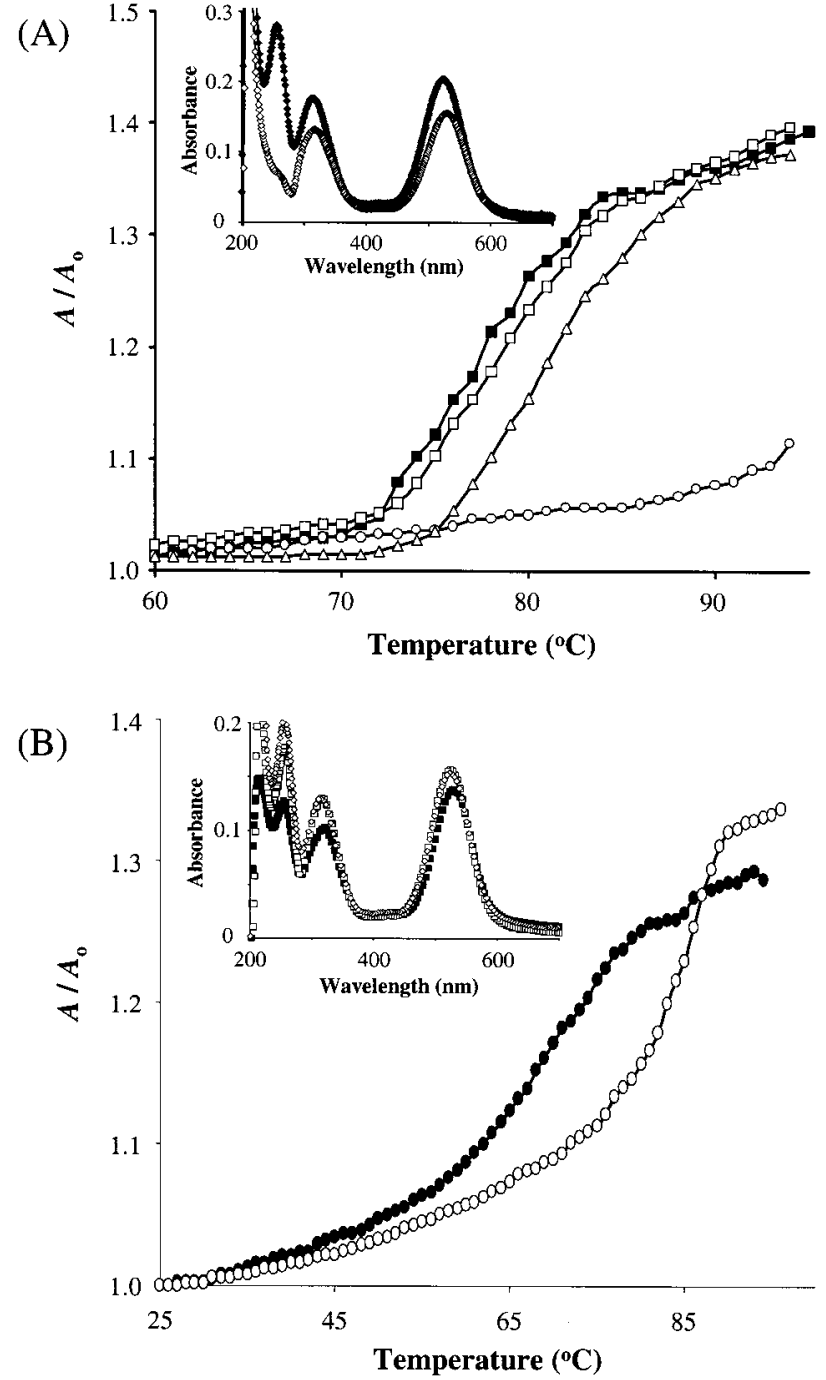

Figure 4. (A) ctDNA $\left(2.60 \times 10^{-5} \mathrm{M}\right.$ in base pairs $)$ melting curves in the absence ( $\square)$ and presence of $\mathbf{1}(\square), \mathbf{2}(\triangle)$, and $\mathbf{3}(\mathrm{O})$ with a 1:1 molar ratio of metal complex to DNA base pair in $5 \mathrm{mM}$ Tris, $50 \mathrm{mM} \mathrm{NaCl}, \mathrm{pH}$ 7.2. Inset: $\mathrm{UV}-$ vis spectra of $\mathbf{3}\left(2.60 \times 10^{-5} \mathrm{M}\right.$ in base pairs $)$ in the absence $(\diamond)$ and presence $(\diamond)$ of ctDNA $\left(2.60 \times 10^{-5} \mathrm{M}\right.$ in base pairs $)$ at $90{ }^{\circ} \mathrm{C}$ in $5 \mathrm{mM}$ Tris, $50 \mathrm{mM} \mathrm{NaCl}$, pH 7.2. (B) 33-bp DNA $\left(1.65 \times 10^{-5} \mathrm{M}\right.$ in base pairs) melting curves in the absence $(\bullet)$ and presence of $\mathbf{3}(O)$ with a 1:1 molar ratio of metal complex to DNA base pair in $5 \mathrm{mM}$ Tris, $50 \mathrm{mM}$ $\mathrm{NaCl}, \mathrm{pH}$ 7.2. Inset: $\mathrm{UV}-$ vis spectra of $\mathbf{3}\left(1.65 \times 10^{-5} \mathrm{M}\right)$ in the absence $(\diamond)$ and presence of 33-bp DNA $\left(1.65 \times 10^{-5} \mathrm{M}\right.$ in base pairs $)$ at $20^{\circ} \mathrm{C}$ (匹) and $90{ }^{\circ} \mathrm{C}(\square)$ in $5 \mathrm{mM}$ Tris, $50 \mathrm{mM} \mathrm{NaCl}, \mathrm{pH} 7.2$.

did not cause significant spectral change at either $20^{\circ} \mathrm{C}$ or $90{ }^{\circ} \mathrm{C}$. The results indicated that broad and red-shifted absorption spectrum of $\mathbf{3}$ in the presence of ctDNA was caused by the intercalation of the chromophore into the double helix and not binding to the ssDNA or the phosphate backbone.

Instead of genomic ctDNA, a 33-bp DNA with lower $T_{\mathrm{m}}$ was also used. The melting curves of 33-bp DNA in the absence and presence of $\mathbf{3}$ are shown in Figure 4B. The $T_{\mathrm{m}}$ of 33-bp DNA was found to be $71{ }^{\circ} \mathrm{C}$, and it was raised to $83{ }^{\circ} \mathrm{C}$ in the presence of 3 . Increase in thermal stability of DNA duplex caused by the formation of DNA-intercalator adduct is commonly observed. ${ }^{23}$ The absorption spectra of 3 in the presence of 33-bp DNA at 20 and $90{ }^{\circ} \mathrm{C}$ are shown in the inset of Figure 4B. Hyperchromism and red shift at 


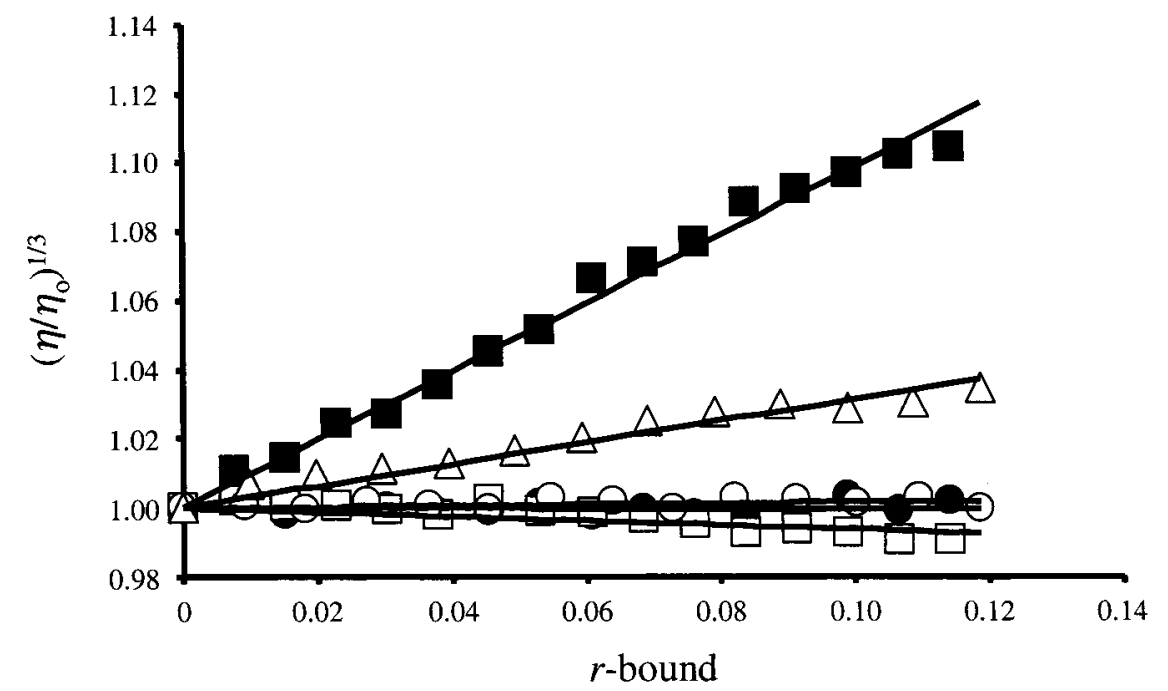

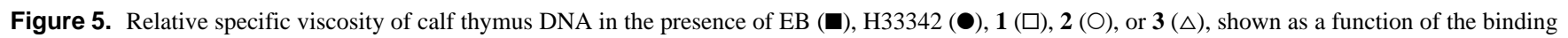
ratio.

319 and $530 \mathrm{~nm}$ were observed as the temperature of solution increased from 20 to $90{ }^{\circ} \mathrm{C}$. Also, the absorption spectrum of $\mathbf{3}$ in the presence of 33-bp DNA at $90{ }^{\circ} \mathrm{C}$ resembled that of $\mathbf{3}$ in the absence of DNA at $90{ }^{\circ} \mathrm{C}$. These results also establish that the spectral changes accompany the binding of $\mathbf{3}$ to DNA are reversible and that the chromophore was not destroyed or chemically altered in the binding process. ${ }^{22}$ The results support intercalation of $\mathbf{3}$ into the double-helical DNA.

The DNA binding constants of $\mathbf{3}$ at $83{ }^{\circ} \mathrm{C}$ was determined by McGhee's equation (eq 2), ${ }^{24}$

$$
\left(1 / T_{\mathrm{m}}{ }^{\mathrm{o}}-1 / T_{\mathrm{m}}\right)=\left(\Delta H_{\mathrm{m}} / R\right) \ln (1+K L)^{1 /} n
$$

where $T_{\mathrm{m}}{ }^{\circ}$ is the melting temperature of ctDNA alone, $T_{\mathrm{m}}$ is the melting temperature in the presence of metal complex, $\Delta H_{\mathrm{m}}$ is the enthalpy of DNA melting (per bp), $R$ is the gas constant, $K$ is the DNA binding constant at $T_{\mathrm{m}}, L$ is the free ligand concentration (approximated at the $T_{\mathrm{m}}$ by the total ligand concentration), and $n$ is the binding site size. A value of $\Delta H_{\mathrm{m}}=7.0 \pm 0.3 \mathrm{kcal} \mathrm{mol}^{-1}$ was used. ${ }^{25}$ On the basis of the neighbor exclusion principle, the $n$ value for $\mathbf{3}$ was assumed to be $2.0 \mathrm{bp}$. By substituting the required parameters to eq $2, K$ was determined to be $2.0 \times 10^{2} \mathrm{M}^{-1}$ at $83^{\circ} \mathrm{C}$ for 3.

The standard enthalpy and standard entropy of $\mathbf{3}$ binding to 33-bp DNA were determined by van't Hoff's equation (eq 3) and the standard free energy change (eqs 4 and 5)

$$
\begin{gathered}
\ln \left(K_{1} / K_{2}\right)=\left(\Delta H^{\circ} / R\right)\left(T_{1}-T_{2} / T_{1} T_{2}\right) \\
\Delta G^{\circ}=-R T \ln K \\
\Delta G^{\circ}=\Delta H^{\circ}-T \Delta S^{\circ}
\end{gathered}
$$

where $K_{1}$ and $K_{2}$ are the DNA binding constants of $\mathbf{3}$ at temperature $T_{1}$ and $T_{2}$, respectively. $\Delta G^{\circ}, \Delta H^{\circ}$, and $\Delta S^{\circ}$ are the standard free energy change, standard enthalpy, and standard entropy of $\mathbf{3}$ binding to 33-bp DNA, respectively. By substituting $K_{1}=5.0 \times 10^{4} \mathrm{M}^{-1}\left(T_{1}=293 \mathrm{~K}\right)$ and $K_{2}=$ $2.0 \times 10^{2} \mathrm{M}^{-1}\left(T_{2}=356 \mathrm{~K}\right)$ into eq $3, \Delta H^{\circ}$ is found to be
$-18 \mathrm{kcal} \mathrm{mol}^{-1}$. By substituting $K=5.0 \times 10^{4} \mathrm{M}^{-1}(T=$ $293 \mathrm{~K}$ ) into eq $4, \Delta G^{\circ}=-6.3 \mathrm{kcal} \mathrm{mol}^{-1}$ at $20^{\circ} \mathrm{C}$. By eq $5, \Delta S^{\circ}=-40 \mathrm{cal} \mathrm{mol}^{-1} \mathrm{~K}^{-1}$ at $20^{\circ} \mathrm{C}$. According to the thermodynamic profile, the favorable binding free energy $\left(-6.3 \mathrm{kcal} \mathrm{mol}^{-1}\right)$ resulted from the difference between the negative enthalpic contribution $\left(-18 \mathrm{kcal} \mathrm{mol}^{-1}\right)$ and the unfavorable entropic contribution $\left(T \Delta S^{\circ}=-11.7 \mathrm{kcal}\right.$ $\mathrm{mol}^{-1}$ ) at $20^{\circ} \mathrm{C}$.

Negative binding free energy means that the energy of free complex 3 and DNA is higher than that of the adduct, and the binding of $\mathbf{3}$ and DNA is favorable at $20^{\circ} \mathrm{C}$. The binding of $\mathbf{3}$ and DNA is exothermic according to the negative enthalpy. Negative entropy implies that the degree of freedom is decreased after $\mathbf{3}$ and DNA binding, and it is thermodynamically unfavorable. Unfavorable entropy might result from reduced DNA conformational freedom upon ligand-DNA binding. Therefore, the conformational change of DNA induced by $\mathbf{3}$ binding was studied by various techniques.

Conformational Change of DNA Induced by the Ru(II) Complex Binding. Viscosity measurements, gel mobility shift assay, and restriction endonuclease fragmentation assay demonstrate the conformational changes in macromolecules, while circular dichroism provides information about the relative orientation of bound metal complex and the oriented helical axis. Intercalation produces an extension, unwinding, and stiffening of the DNA helix. These changes are a consequence of the untwisting of the base pairs and helical backbone needed to accommodate the intercalator. $^{21}$

According to the theory of Cohen and Eisenberg, ${ }^{26}$ viscosity data were plotted as $\left(\eta / \eta_{\mathrm{o}}\right)^{1 / 3}$ versus the binding ratio $r$-bound, and the plot was shown in Figure 5. $\left(\eta / \eta_{\mathrm{o}}\right)^{1 / 3}$

(23) (a) Remeta, D. P.; Mudd, C. P.; Berger, R. L.; Breslauer, K. J. Biochemistry 1993, 32, 5064-5073. (b) Neidle, S.; Pearl, L. H.; Skelly, J. V. Biochem. J. 1987, 243, 1-13.

(24) McGhee, J. D. Biopolymers 1976, 15, 1345.

(25) Chaires, J. B.; Leng, F.; Przewloka, T.; Fokt, I.; Ling, Y.-H.; PerezSoler, R.; Priebe, W. J. Med. Chem. 1997, 40, 261.

(26) Cohen, G.; Eisenberg, H. Biopolymers 1969, 8, 45-55. 
(A)

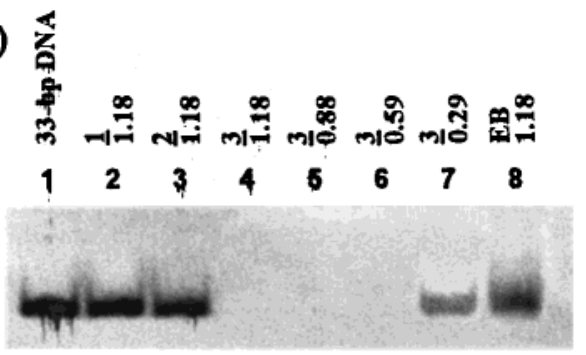

(B)

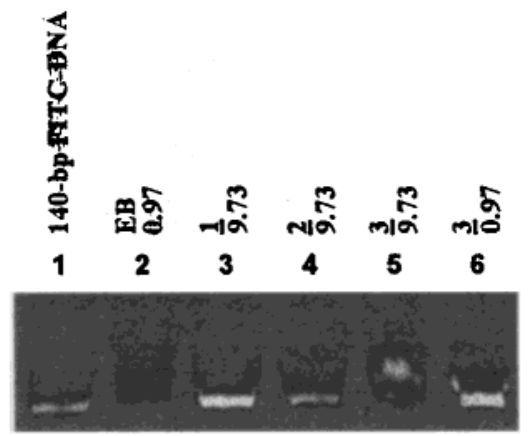

Figure 6. (A) Electrophoresis of 33-bp DNA in a $20 \%(\mathrm{w} / \mathrm{v})$ polyacrylamide gel showing the mobility of DNA $\left(1.7 \times 10^{-4} \mathrm{M}\right.$ in base pairs) in the absence (lane 1) and presence of various compounds labeled with the [compound]/[bp] (lanes 2-8). (B) Electrophoresis of a 140-bp FITC-labeled DNA in a $15 \%(\mathrm{w} / \mathrm{v})$ polyacrylamide gel showing the mobility of DNA $\left(7.5 \times 10^{-7} \mathrm{M}\right.$ in base pairs) in the absence (lane 1$)$ and presence of various compounds labeled with the [compound]/[bp] (lanes 2-6).

is proportional to $L / L_{0}$, where $\eta$ and $L$ are the relative viscosity and length for rodlike DNA in the presence of ligand, respectively, and the subscript o indicates that the parameters were determined in the absence of ligand. Apart from the $\mathrm{Ru}(\mathrm{II})$ complexes, the viscosity data of two other ligands, EB (intercalator) and Hoechst 33342 (H33342) (groove binder), were also plotted. Straight lines with different slope were obtained.

Intercalator dramatically increases the hydrodynamic length of DNA. On the contrary, groove binder does not lengthen the DNA molecules and does not increase the viscosity of DNA solutions. ${ }^{13}$ Among the three $\mathrm{Ru}(\mathrm{II})$ complexes, only $\mathbf{3}$ induced a significant increase in the viscosity of rodlike DNA. The effective length increase in DNA produced by binding of $\mathbf{3}$, calculated from the viscosity results of Figure 5 with the method of Cohen and Eisenberg, ${ }^{26}$ is only approximately one-third of that produced by ethidium binding. Viscosity measurements sensitively detect the lengthening and unwinding of DNA helix induced by the binding of intercalators. ${ }^{13}$ In the absence of high-resolution data obtained by X-ray diffraction methods or NMR, viscosity studies provided convincing proof of intercalation of 3 .

Gel mobility shift assay is another method to demonstrate DNA lengthening. Lengthening of DNA molecules increased the frictional force between DNA and the gel matrix during electrophoresis. As a result, the band corresponding to the intercalator-DNA adduct moved relatively slower than the band of DNA alone. The results of gel electrophoresis of 33-bp DNA and FITC-labeled 140-bp DNA in the absence and presence of $\mathbf{1}, \mathbf{2}$, and $\mathbf{3}$ are shown in Figure 6. Both lanes 1 of Figure 6A,B were the DNA without addition of
DNA binding agents and the metal complexes, and acted as a reference for any mobility shift in other samples.

In the case of 33-bp DNA without labeling, after electrophoresis, EB staining gave clear bands for $\mathbf{1}$ and 2, but not for 3 . The DNA band was only observed at a relatively low $[3] /[\mathrm{bp}](0.30: 1)$. However, the band was invisible at higher $[3] /[b p]$. Disappearance of the DNA band was probably caused by quenching of the EB fluorescence by $\mathbf{3}$. To find out where the DNA was, a FITC-labeled dsDNA was used.

In lane 1 of Figure $6 \mathrm{~B}$, a single band was observed for 140-bp DNA in the absence of small molecules. A similar observation was found for $\mathbf{1}$ and $\mathbf{2}$ at [complex]/[bp] of (5.6:1). However, in the presence of a classical intercalator (EB), band tailing and smearing occurred. At [3]/[bp] of (5.6:1), significant mobility shift of the DNA was observed. Similar to EB, DNA molecules moved relatively slower than that in lane 1. It indicated that DNA was lengthened by 3 and EB, and it provided evidence of the induction of DNA conformational change by $\mathbf{3}$.

Enzymatic DNA cleavage is inhibited when the local conformation of the enzyme binding site or the restriction site is altered upon the binding of ligand, and possibly when the groove sensed by the enzyme is blocked by ligand. ${ }^{23 b}$ Apart from intercalator, groove binder and DNA crosslinking agent can also protect DNA from enzymatic cleavage by covering the restriction site and disrupting the local structure of dsDNA, respectively. ${ }^{27}$ The results of electrophoresis of pDR2 after restriction enzyme digestion in the absence and presence of small molecules are shown in Figure 7. Two bands, corresponding to supercoiled and nickedcircular DNA, were observed in the undigested DNA, lane 2. After ApaI digestion of $\mathrm{pDR} 2$, lane 3, three bands, corresponding to the DNA fragments of 8,5 , and $2 \mathrm{kbp}$, were observed. In the presence of classical intercalator (EB), minor groove binder (H33342), and intrastrand cross-linker (cisplatin), digestion of plasmid was not complete, since bands correspond to both whole plasmid and DNA fragments were found. In the presence of a high [3]/[bp] $(6.7: 1)$, complete inhibition of ApaI digestion was found, while partially inhibited cleavage was observed at lower molar ratios. However, even at [complex]/[bp] (67:1) of $\mathbf{1}$ or $\mathbf{2}$, complete digestion of plasmid was still observed. The results indicated that the enzymatic digestion of plasmid was inhibited by DNA binding molecules such as intercalator, groove binder, and cross-linker. It showed that $\mathbf{3}$ interacted with DNA or restriction endonuclease. On the basis of the results obtained from the three different techniques, only 3 can induce significant conformational changes in DNA, and it was held rigidly by the DNA double helix.

In the $\mathrm{CD}$ experiment, no $\mathrm{CD}$ spectra were induced for $\mathbf{1}$ and 2 with ctDNA. This is in agreement with absorption spectra for the complexes with ctDNA, on which no or small changes of absorption spectra were observed. CD spectrum is also a kind of absorption spectrum, using polarized light

(27) (a) Shelton, C. J.; Harding, M. M.; Prakash, A. S. Biochemistry 1996, 35, 7974-7982. (b) Holler, E. In Metal Complexes in Cancer Chemotherapy; Keppler, B. K., Ed.; VCH: New York, 1993, p 44. 


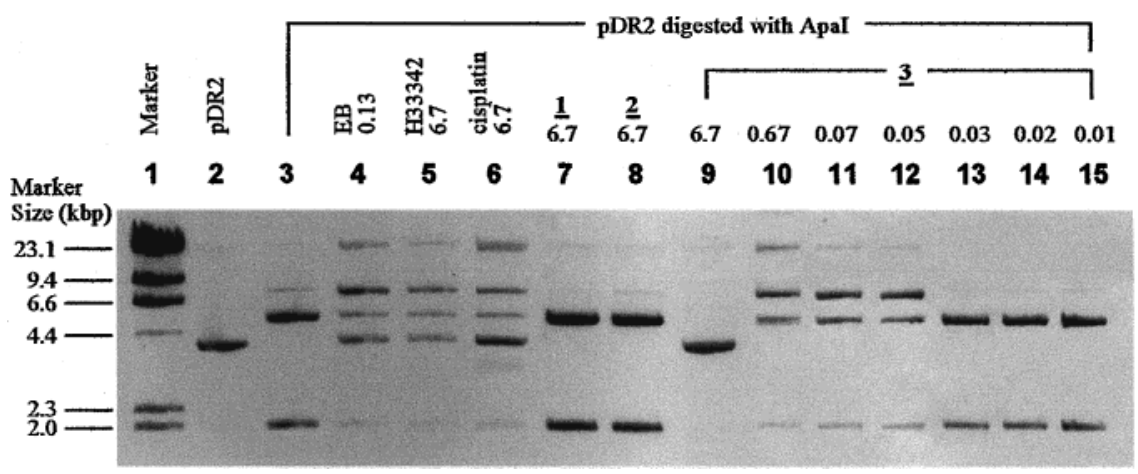

Figure 7. Electrophoresis of a $10.7 \mathrm{kbp}$ plasmid (pDR2) in $1 \%(\mathrm{w} / \mathrm{v})$ agarose gel after restriction enzyme (ApaI) digestion in the absence (lane 3$)$ and presence (lanes 4-15) of various compounds labeled with the [compound]/[bp]. Lane 2 is the undigested DNA.

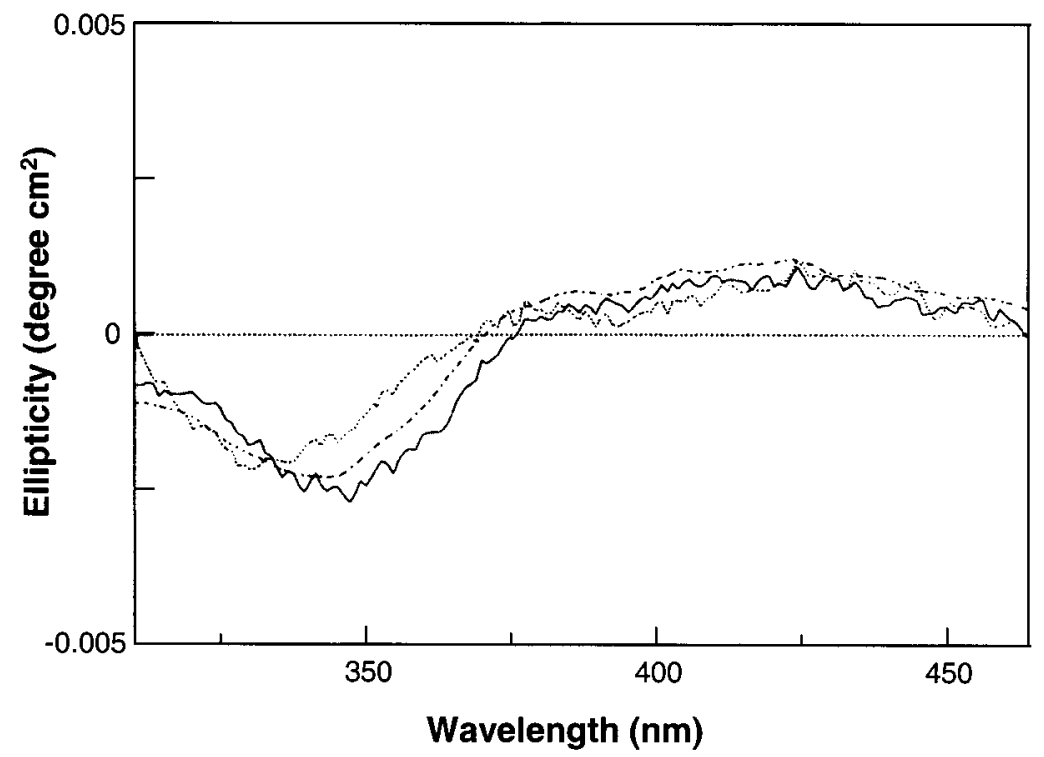

Figure 8. Induced $\mathrm{CD}$ spectra of $3\left(2.86 \times 10^{-5} \mathrm{M}\right)$ in Tris buffer solution in the presence of ctDNA $\left(2.14 \times 10^{-4} \mathrm{M}\right.$ in base pairs $)(-\cdot-)$, [poly(dG-dC) $]_{2}$ $\left(2.14 \times 10^{-4} \mathrm{M} \text { in base pairs) }(\cdots) \text {, and [poly(dA-dT) }\right]_{2}\left(2.14 \times 10^{-4} \mathrm{M}\right.$ in base pairs) $(-)$ at room temperature.

as light source. Thus, it is expectable for the two different methods to give similar results. The induced CD spectrum of $\mathbf{3}$ and ctDNA (Figure 8) displayed a small positive band at $428 \mathrm{~nm}$ and a relatively large negative band at $344 \mathrm{~nm}$. DNA helix does not display CD spectrum at $\lambda \geq 300 \mathrm{~nm}$. Therefore, the induced $\mathrm{CD}$ spectra observed for $\mathbf{3}$ in the presence of ctDNA were originated from the adduct of $\mathbf{3}$ and DNA and could be considered as an indicator for binding of the complex to ctDNA.

For 3 with $[p o l y(d G-d C)]_{2}$ and [poly(dA-dT) $]_{2}$, it displays similar CD spectra: a positive band at $429 \mathrm{~nm}$ for both $\mathrm{GC}$ and $\mathrm{AT}$ and a negative band at $331 \mathrm{~nm}$ for $\mathrm{GC}$ and at 348 $\mathrm{nm}$ for AT. The induced CD spectra for $\mathbf{3}$ with the two polynucleotides are similar to that with ctDNA on both peak wavelength position and ellipticity, suggesting that $\mathbf{3}$ interacts significantly with both GC and AT sites when it binds to ctDNA, as indicated in absorption titration. The results of $\mathrm{CD}$ also indicated that $\mathbf{3}$ showed similar binding preference for both GC and AT sites on DNA, and it is consistent with the results of absorption measurements.

Cytotoxicity of the $\mathbf{R u}(\mathrm{II})$ Complexes. The $\mathrm{IC}_{50}$ of the $\mathrm{Ru}$ (II) complexes in two human epidermal carcinomas KB-3-1 and KB-V1 (originated from cervix carcinoma) are summarized in Table 4. The $\mathrm{Ru}(\mathrm{II})$ complexes showed
Table 4. Cytotoxicity of Ruthenium(II) Quinonediimine Complexes of Cyclam in Human Carcinomas KB-3-1 Cells and Its Multidrug-Resistant Subclone KB-V1 Cells

\begin{tabular}{ccc}
\hline & \multicolumn{2}{c}{$D_{\mathrm{m}}{ }^{a}, \mathrm{M}$} \\
\cline { 2 - 3 } cmpd & KB-3-1 & KB-V1 \\
\hline $\mathbf{1}$ & $(1.42 \pm 0.79) \times 10^{-3}$ & $(2.02 \pm 0.85) \times 10^{-3}$ \\
$\mathbf{2}$ & $(8.26 \pm 4.02) \times 10^{-4}$ & $(1.19 \pm 0.03) \times 10^{-3}$ \\
$\mathbf{3}$ & $(2.89 \pm 0.23) \times 10^{-4}$ & $(4.47 \pm 0.06) \times 10^{-4}$
\end{tabular}

${ }^{a}$ The median dose value $\left(D_{\mathrm{m}}\right)$ was determined from plots of median effects and is equivalent to the $\mathrm{IC}_{50}$.

similar $\mathrm{IC}_{50}$ in both $\mathrm{KB}-3-1$ and $\mathrm{KB}-\mathrm{V} 1$ cell lines. The $\mathrm{IC}_{50}$ of $\mathbf{3}$ was smaller than that of $\mathbf{1}$ by an order of magnitude, and $\mathbf{2}$ showed similar cytotoxicity as $\mathbf{1}$. Cytotoxicity of the three $\mathrm{Ru}(\mathrm{II})$ complexes was relatively low when compared with other DNA binding metal complexes, for example, $[\mathrm{Pt}(\mathrm{dppz})(t \mathrm{~N} \wedge \mathrm{C})] \mathrm{CF}_{3} \mathrm{SO}_{3}$ (dppz = dipyrido[3,2-a:2, $\left.3^{\prime}-c\right]-$ phenazine, $t \mathrm{~N} \wedge \mathrm{C}=4$-tert-butyl-2-phenylpyridine) $\left(\mathrm{IC}_{50}\right.$ in $\mathrm{KB}-3-1$ and $\mathrm{KB}-\mathrm{V} 1$ are $1.7( \pm 0.5) \times 10^{-6} \mathrm{M}$ and $1.0( \pm 0.5)$ $\times 10^{-6} \mathrm{M}$, respectively). ${ }^{28}$ Although 3 showed DNA binding, the cytotoxicity of $\mathbf{3}$ was not significantly higher than that of $\mathbf{1}$ and $\mathbf{2}$. The major difference between KB-3-1 and KB-

(28) Che, C.-M.; Yang, M.; Wong, K.-H.; Chan, H.-L.; Lam, W. Chem.Eur. J. 1999, 5, 3350-3355. 

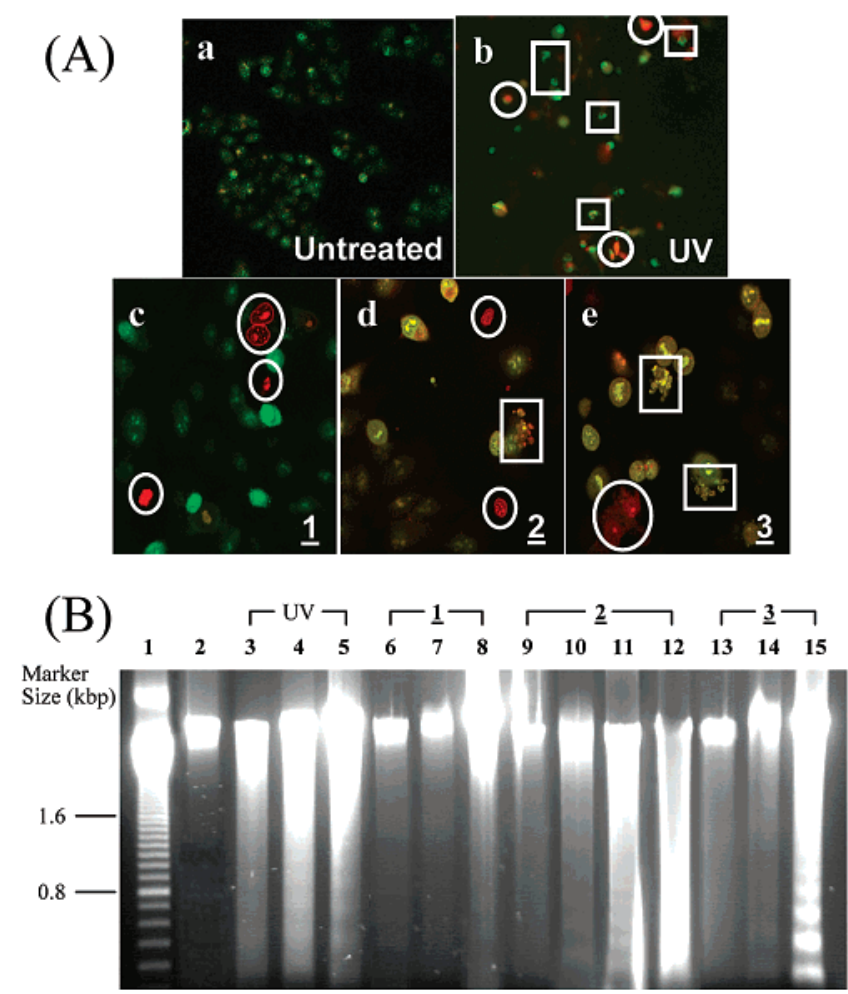

Figure 9. (A) KB-3-1 cells were stained by AO/EB and observed under laser scanning confocal microscopy. KB-3-1 cells without treatment (a), and irradiated with $60 \mathrm{~mJ} / \mathrm{cm}^{2} \mathrm{UV}-\mathrm{C}(\mathrm{b})$, and in the presence of $\mathbf{1}(7.1 \times$ $\left.10^{-4} \mathrm{M}\right)(\mathrm{c}), 2\left(4.1 \times 10^{-4} \mathrm{M}\right)(\mathrm{d})$, and $\mathbf{3}\left(1.4 \times 10^{-4} \mathrm{M}\right)(\mathrm{e})$ incubated at $37^{\circ} \mathrm{C}$ and $5 \% \mathrm{CO}_{2}$ for $72 \mathrm{~h}$. Cells in circle and rectangle are necrotic and apoptotic cells, respectively. (B) Electrophoretic analysis of genomic DNA extracted from KB-3-1 cells under different treatment: $60 \mathrm{~mJ} / \mathrm{cm}^{2} \mathrm{UV}-\mathrm{C}$ irradiation (lanes 3-5); incubation in the presence of $1\left(7.1 \times 10^{-4} \mathrm{M}\right)$ (lanes 6-8), $2\left(4.1 \times 10^{-4} \mathrm{M}\right)$ (lanes 9-11), and $\mathbf{3}\left(1.4 \times 10^{-4} \mathrm{M}\right)$ (lanes $12-14)$. Genomic DNAs of the treated cells were collected at different time points: $6 \mathrm{~h}$ (lanes 3,6,9, and 12), $12 \mathrm{~h}$ (lanes 4, 7, 10, and 13), and $24 \mathrm{~h}$ (lanes 5, 8, 11, and 14). Lane 1 is a 100-bp DNA ladder (Amersham Pharmacia Biotech). Lane 2 is DNA extracted from untreated cells.

V1 cells was the number of membrane P-glycoprotein. P-Glycoprotein was an efficient pump for drugs such as vinblastin, doxorubicin, and so forth, but it seemed to be ineffective for the metal complexes studied.

Cell death can be divided into two types, necrosis ("accidental" cell death) and apoptosis ("programmed" cell death) ${ }^{29}$ Necrosis causes severe inflammation, but apoptosis does not. Harmlessly disposing of cells (for example, cancer cells) is one of the considerations in chemotherapy. ${ }^{30}$ Therefore, induction of apoptosis is one of the considerations in drug development. Most of the cytotoxic anticancer drugs in current use have been shown to induce apoptosis in susceptible cells. ${ }^{31}$

The type of cell death induced by the Ru(II) complexes was identified by the cell morphology and the fragmentation of genomic DNA. Pictures of the cells are shown in Figure 9. In the untreated sample, the nucleoli of a living cell were stained as bright green spots in the nucleus. However, after irradiation with $60 \mathrm{~mJ} / \mathrm{cm}^{2} \mathrm{UV}-\mathrm{C}$ or in the presence of the

(29) (a) Schwartzman, R. A.; Cidlowski, J. A. Endocr. Rev. 1993, 14, $133-$ 151. (b) Vermes, I.; Haanen, C. Adv. Clin. Chem. 1994, 31, 177246.

(30) Thornberry, N. A.; Lazebnik, Y. Science 1998, 281, 1312-1316.

(31) Hickman, J. A. Cancer Metastasis Rev. 1992, 11, 121-139. three $\mathrm{Ru}(\mathrm{II})$ complexes, orange necrotic cells with nuclear morphology resembling that of viable cells were observed. In addition, green apoptotic cells with apoptotic bodies were found in cells treated with UV, 2 , and $\mathbf{3}$. In the DNA ladder analysis (Figure 9), the genomic DNA of the treated and untreated KB-3-1 cells were analyzed by gel electrophoresis. Genomic DNA of chromosome size was found in the untreated sample, and no fragmentation was observed. Distinctive DNA ladders, consisting of multiples of an approximately 180-bp subunit, were observed in the DNA samples extracted from cells irradiated with UV, then incubated for 12 and $24 \mathrm{~h}$ (lanes 4 and 5), and as well as cells incubated in the presence of $\mathbf{2}$ for $18 \mathrm{~h}$ (lane 11) and $\mathbf{3}$ for $24 \mathrm{~h}$ (lane 15). No DNA ladder was observed in the other samples. Only smearing and tailing, but no DNA ladder, were found in the cells treated with complex $\mathbf{1}$. It was caused by postlytic DNA fragmentation, which was a biochemical feature of necrosis, ${ }^{32}$ and resulted in the formation of DNA fragments of various length. The results of the DNA ladder analysis were consistent with that of the AO/EB staining. According to the results of DNA binding studies and type of cell death analysis, it seemed that there was a correlation between DNA binding activities and apoptosis inducing properties of the metal complexes studied.

In this study, three novel $\mathrm{Ru}$ (II) quinonediimine complexes of cyclam were synthesized and characterized. Their DNA binding properties and biological activities such as cytotoxicity and induced cell death were also investigated. The bqdi ligand of $\mathbf{1}$ is the least protruded ligand among the three $\mathrm{Ru}(\mathrm{II})$ complexes, so it is not surprising that $\mathbf{1}$ shows no detectable intercalation. In absorption titration of $\mathbf{2}$ with ctDNA, changes in the absorption spectrum were too small to allow for the determination of the DNA affinity of $\mathbf{2}$. It implied that although the nqdi ligand of $\mathbf{2}$ extends well away from the metal center, it does not have substantial $\pi-\pi$ overlap with the base pairs. The phi ligand of $\mathbf{3}$ is flat, large in surface area, and has a geometry that permits substantial overlap with the base pairs, when compared with the nqdi ligand of $2 .^{1 f}$ The DNA affinity of $\mathbf{3}$ is in a similar magnitude as other $\mathrm{Ru}(\mathrm{II})$ complexes of phi. ${ }^{1 \mathrm{f}}$ It is not surprising that only 3 interacts with DNA significantly, because metal complexes of phi were proved to intercalate with DNA. ${ }^{3 \mathrm{~b}, 33}$ Only 3 out of these three Ru(II) quinonediimine complexes of cyclam shows a DNA binding affinity of $5.0 \times 10^{4} \mathrm{M}^{-1}$ at $20{ }^{\circ} \mathrm{C}$. Compound $\mathbf{3}$ does not show a significantly high DNA affinity and distinctive base pair preference, compared with other metal complexes such as $\left[\mathrm{Ru}(\mathrm{bpy})_{2}(\mathrm{phi})\right]^{2+}(4.8$ $\left.\times 10^{4} \mathrm{M}^{-1}\right),{ }^{1 \mathrm{f}}\left[\mathrm{Ru}(\mathrm{phen})_{2}(\mathrm{phi})\right]^{2+}\left(4.7 \times 10^{4} \mathrm{M}^{-1}\right),{ }^{1 \mathrm{f}}$ $\left[\operatorname{Re}(\mathrm{dppz})(\mathrm{CO})_{3}(\mathrm{py})\right]\left(\mathrm{CF}_{3} \mathrm{SO}_{3}\right)\left(4.2 \times 10^{4} \mathrm{M}^{-1}, \mathrm{~A} \cdot \mathrm{T}\right.$ preference $){ }^{34}\left[\operatorname{Re}(\mathrm{dppn})(\mathrm{CO})_{3}(\mathrm{py})\right]\left(\mathrm{CF}_{3} \mathrm{SO}_{3}\right)\left(6.4 \times 10^{4} \mathrm{M}^{-1}\right.$, $\mathrm{A} \cdot \mathrm{T}$ preference $){ }^{34}$ and $[\mathrm{Pt}(\mathrm{phen})(\mathrm{en})]^{2+}\left(5 \times 10^{4} \mathrm{M}^{-1}\right.$,

(32) In Apoptosis and Cell Proliferation, 2nd ed.; Eisel, D., Fertig, G., Fischer, B., Manzow, S., Schmelig, K., Eds.; Boehringer Mannheim GmbH, Biochemica: Germany, 1998.

(33) Krotz, A. H.; Kuo, L. Y.; Shields, T. P.; Barton, J. K. J. Am. Chem. Soc. 1993, 115, 3877-3882.

(34) Yam, V. W.-W.; Lo, K. K.-W.; Cheung, K.-K.; Kong, R. Y.-C. J. Chem. Soc., Dalton Trans. 1997, 2067-2072. 
$\mathrm{G} \cdot \mathrm{C}$ preference $)^{35}\left(\mathrm{dppn}=\right.$ benzo $[i] \operatorname{dipyrido}\left[3,2-a: 2^{\prime}, 3^{\prime}-c\right]-$ phenazine, py $=$ pyridine, phen $=1,10$-phenanthroline, and en $=$ ethane-1,2-diamine). Results of the various biophysical and cytological tests indicated that metal complexes with ligands of molecular shape closely related to the structure of DNA are more likely to bind DNA and possess higher toxicity. None of the Ru(II) cyclam complexes investigated in this study is a potent cytotoxic agent against carcinoma,

(35) Howe-Grant, M.; Lippard, S. J. Biochemistry 1979, 18, 5762-5769. because the $\mathrm{IC}_{50}$ of them are relatively high when compared with other metal complexes. ${ }^{28}$

Acknowledgment. We acknowledge support from the Hong Kong Research Grants Council (CityU 1189/01P) and the Area of Excellence Scheme, University Grants Committee (Hong Kong).

IC0112802 